\title{
Music and its Role in the Electoral Process of Zambia
}

\author{
Mubita Namuyamba $^{*}$, Wanga, W. Chakanika ${ }^{2}$, Friday Nyimbili ${ }^{3}$, Kabwe Chisenga ${ }^{4}$, \\ Munkombwe Conrad ${ }^{5}$, Davies Phiri ${ }^{6}$ \\ ${ }^{1}$ Part- Time Lecturer Department of Adult Education and Extension Studies at the University of Zambia \\ ${ }^{2}$ Senior Lecturer- University of Zambia, School of Education, DAEES. P.O. Box 32379, Lusaka \\ ${ }^{3}$ Secondary School, Teacher Ministry of Education, Zambia. PhD Student (Applied Linguistics), University of \\ Zambia \\ ${ }^{4}$ Senior Community Development Officer - Ministry of Community Development and Social Services, Zambia. \\ Former Postgraduate Student (Master of Education in Adult Education), University of Zambia \\ ${ }^{5}$ Researcher and writer. Head of Section for Intergrated Sceince at Njanse Secondary School Senior Teacher, \\ Ministry of Education, Zambia. He holds MAE and BAED from the University of Zambia \\ ${ }^{6}$ Lecturer, and researcher at the University of Zambia Department of Adult Education and Extension Studies \\ *Corresponding Author: Mubita Namuyamba, Part- Time Lecturer Department of Adult Education and \\ Extension Studies at the University of Zambia
}

\begin{abstract}
The purpose of the study was to assess music and its role in the electoral process of Zambia. The study adopted a qualitative design using an open ended questionnaire, a focus group discussion guide and an interview guide on a sample of 170 respondents. Purposive sampling procedure was used to identify musicians who were employed by politicians belonging the Patriotic Front (PF) and the United Party for National Development (UPND). Data was analysed according to themes that emerged in line with the research questions. Responses were grouped and a detailed interpretation was given in line with the main research question. The findings were that well composed political music had a huge influence on the candidate people voted for as music helped to pull the crowd, sell candidates and their manifestos, empower and educated the learners and substituted public rallies in unbreakable to reach areas. The other finding was that popularity of the musicians used added value to the politicians on stage. This helped the politicians to talk little since many words were in the songs performed before the stage and or on radio. The study also unearthed that politicians and musicians used Bemba, Nyanja and English in their political music as these were the three widely spoken languages in the country. The study recommends that: politicians should not use music as a conveyer of propaganda, but should continue informing the nation on the development and failures encountered in the nation throughout the term of rule; voters should compare what they hear from the music with the reality on the ground so that they are able to cast a vote from an informed and practical decision.; musicians should stand their ground of informing, entertaining and educating and be in a position to refuse to be used as tools for spreading propaganda and ridicule of one person for the sake of another person; and that more regional languages have to be used in order to promote the one Zambia one nation slogan despite Bemba, Nyanja and English being the widely used languages.
\end{abstract}

Keywords: Music, Role, Electoral Process of Zambia.

\section{INTRODUCTION}

For many years, several musicians and bands have used their music as a vehicle to express their political views. From Verdi to Pussy Riot, these artists use songs and performances to spark movements (Wood, 2012). As long as there are policies and issues to rage against, these artists and bands will keep making sure their voices get heard. Great nations have used music to advance their political ambitions and propaganda. Dunaway (1987) observed that the instinct to voice political sentiments through music was not new and unique. The Chinese emperors sent organized and sent officers to record songs of masons building the Great Wall as a rudimentary opinion poll. The aims of the emperors were achieved in the due course since the perception of people was changed through music. 
Music and art in general have played a significant role in the world to communicate specific messages to the audience and country as a whole. This realization was observed by the early musicians and artists earlier than 1800. For a number of years, folk music commented on politics directly. A good example is the song, "We Shall Overcome," perhaps the best-known folk protest song, was taken from an early gospel song, "I'll Overcome Someday" by African-American composer Charles Albert Tindley (UNESCO, 1953). The tune was made popular by Pete Seeger and Joan Baez. It was used as a theme during the Civil Rights Movement. "Where Have All the Flowers Gone?" by Pete Seeger became a popular protest song during the Vietnam War. Bob Dylan's "Blowin' in the Wind" helped usher in a younger generation's discontent with the beliefs and politics of older generations (Bochkarev, 2012).

(Wood, 2012 and Hayden, 1962) wrote that in the United States and at the 1968 Democratic Convention in Chicago, the underground rock band MC5 performed. After their performance, a riot broke out between police and students who were protesting the assassination of Dr. Martin Luther King, Jr., and the Vietnam War. MC5, known for its countercultural lyrics in songs like "The American Ruse", did not participate in the riot.

In 2000 and 2008, RATM played free shows outside the Democratic National Conventions. In 2000, the show was a protest against the two-party system. In 2008, the free concert was to protest against the war in Iraq. After the 2008 performance, they participated in an anti-war protest march led by Iraq Veterans Against the War. The Washington Post (2016) cited that during the 2012 presidential election campaign, vice presidential candidate Paul Ryan said that RATM was one of his favourite bands. Guitarist Tom Morello responded in an opted piece on Rolling Stone's website: Paul Ryan's love of Rage Against the Machine is amusing, because he is the embodiment of the machine that our music has been raging against for two decades. Charles Manson loved the Beatles, but didn't understand them. This was a sign the listeners hardly understood all what the music portrayed in the real sense despite enjoying the music.

Through oral tradition, songs and performances are perceived as a stronger tool for change since the songs are performed and played to every person with regardless of political affiliation, culture and religion. Plato warned that any musical innovation is full of danger to the whole state hence should be prohibited because music is a driving force for rage hatred and change (Gavish, 2009).

Zambian politics have not been isolated from music and artists being used to sell the political manifesto during campaigns. Independent composers of music firstly used music to put across strong messages of changing the government through satire songs like "common man" by P.K. Chishala in the 1980.Nathan Nyirenda with a song "Wemakufi" in the early 2000 were used by political parties to win sympathy on radio stations. The 2011 political campaigns saw a cluster of musicians like Dandy Crazy with his "Donchikubeba" singing political songs for PF which was ridicule on the MMD government. The message was so strong that the song was a political propaganda for the nation. To the interest of many, the political songs have used Bemba and Nyanja dialects to communicate to the whole nation whose tribal grouping is 73 . The way political parties have come to choose the musicians, the songs and the packaging of words in the songs has been amazing because the impact is huge for the country.

\section{OVERVIEW OF LITERATURE}

In the views of Munshya (2014) there is a long history of the connection between music and politics, particularly political expression in music. This expression can use anti-establishment or protest themes, including anti-war songs, although pro-establishment ideas are also used, for example in national anthems, patriotic songs, and political campaigns. Many of these types of songs could be described as topical songs. Sharing the same view, Philip (2012) indicates that unlike many other types of music, political music is not usually ambiguous, and is used to portray a specific political message. While the political message in political music is apparent, it is usually in the political context of the time it was made which makes understanding the historical events and time that inspired the music essential to fully understanding the message in the music. Since political music is meant to be heard by the people, it is often meant to be popular.

Philip (2012) further asserts that the use of music in the Zambian election campaign has a colonial history in Zambia. For instance, the fight against colonialism was catalyzed by music and other forms 
of popular culture. An example is the influence of the Mbeni and Kalela music and dances on the Copper belt in the 1930s and 1950s. These songs, music and dances, not only played an instrumental role in sensitizing the urban population to the injustices of colonial rule but also developed an effective medium of nationalist agitation against colonialism.

In the perception of Chimuka (1997) during the struggle for independence, Zambia's first president Kenneth Kaunda's Tiyendepamodzi song is another example of how songs were used to mobilize support during the fight against colonialism and white minority rule. The song was also used by Kenneth Kaunda and other nationalist leaders to unit people after independence. 'Tiyendepamodzi' was like an anthem of the nationalist struggle, not only in Zambia but also in southern Africa. It was an energizing song during marches to and from political rallies.

Wilson (2016) argues that the importance of the song lay in its call for Africans to collectively move forward in a united force and spirit. Again towards the campaigns for the re-introduction of multiparty politics in Zambia in the 1990s, musicians and music were seen to be an important feature in the political trajectory from one part to multiparty democracy. In 1991 in particular, the Movement for Multi-Party Democracy (MMD) as a leading opposition political party went on to use songs by popular musicians such as Congolese singer 'TshalaMuana' as a way of mobilizing political support for the October 1991 elections during the campaign rallies.

Brader (2005) noted that the other songs by Zambian musicians such as PK Chishala's 'Common man' were also used by then opposition MMD as a way of expressing the social, economic and political reality and dissatisfaction towards the United Nations Independence Party (UNIP). Further, in 1991 after the endorsement of the last part of the Democratic Republic of the Congo peace agreement in Lusaka by the remaining rebel faction in the DRC, Congolese rhumba musician Suke Chile put together a commemorative prelaunch of his album "Merci papa Chiluba" or Thank you Mr.Chiluba. The music album released that year was a glowing tribute to President Chilubaand the Southern African Development Community (SADC) for their pacific efforts to bring peace to the Democratic Republic of Congo (Cogan, 2009).

Similarly, during the run-up to the 2011 general elections, the opposition Patriotic Front (PF) party carried its campaign message across using the popular song, "Donchikubeba" sung by a local musician Wesley Chibambo, popularly known as Dandy Crazy. The song proved so electric and energizing for the PF campaign message that, no doubt, it contributed to the opposition PF emerging victorious in the September 20, 2011 elections (Lumpa, 2016). Prior to this, a sympathy song by Nathan Nyirenda 'Wemakufi' was a soul moving song played before the PF leader could start presenting on the 'Let the people talk' show on radio. Such songs were packages to provide the will of God yet pointing out the reality happening in the community.

It is, therefore, undeniable that music is a great recruiting and mobilizing tool which has been used by various players in the social and political spectrum to transmit ideology and mobilize political support over time. Therefore, music in Zambia does not only predate colonialism, but also links the country's historical and cultural process with the present (Lumpa, 2016).

A variety of studies have sought to explore the impacts of exposure to political advertising. Franz and Ridout (2010) conducted a study on the Political Advertising and Persuasion in the 2004and 2008 Presidential Elections in America. The results showed some important differences in advertising patterns across years, especially in terms of sponsorship and market level advertising advantages. The study also found some significant and strong advertising persuasion effects in 2008. Goldstein and Freedman (2000) examined the impact of advertising in several United State (U.S.) Senate races using the 1996 cross-sectional American National Election Studies. Their analysis revealed that as exposure to a Senate challenger's advertising increased, the likelihood of voting for that candidate increased as well. The same was true for incumbent advertising.

Chimuka (1997) points out that Zambia has several major indigenous languages, all of them members of the Bantu family, together with English, which is the official language and the major language of business and education. Zambia is widely claimed to have over 72 languages, although many of these might be better regarded as dialects. Some of these languages have a long history within Zambia, while others, such as Lozi, arose as a result of 18th and 19th-century migrations. All of Zambia's vernacular languages are members of the Bantu family and are closely related to one another. Seven 
vernacular languages have official status. Together these represent the major languages of each province: Bemba (Northern Province, Luapula, Muchinga and the Copperbelt), Nyanja (Eastern Province and Lusaka), Lozi (Western Province), Tonga (Southern Province), and Kaonde, Luvale and Lunda (North-western Province). These seven languages are used, together with English, in early primary schooling and in some government publications. A common orthography was approved by the Ministry of Education in 1977 (Chimuka, 1997). According to the 2000 census, Zambia's most widely spoken languages are Bemba (spoken by $52 \%$ of the population as either a first or second language), Nyanja (37\%), Tonga (15\%) and Lozi (11\%).

Munshya (2014) points out that knowledge and good use of language enables us to construct powerful messages that connect with the voters at a deeper and emotional level. Taking inspiration from the great thinkers and poets, of the beauty of literature, interest ourselves a little more about the resources offered by our language, and of course, be constantly observant of the everyday society we live in and how this society perceives and associates, we provide useful tools to distinguish ourselves from our competitors. And who can forget Scrabble's music: "It's our word against theirs."

\section{AIM}

The aim of the study was to assess music and its role in the electoral process of Zambia between 2006 to 2016. The study was guided by three objectives; Assess the influence of music on voters;Establish why politicians use musicians in political campaigns; and to establish the reasons for choosing a language in a political music.

\section{Methodology}

The study used a qualitative design on a population of 160 respondents who included 32 voters from each province making 130 voters, $10 \mathrm{PF}$ and 10 UPND officials from the secretariat who were in the campaign team of the party totalling to 20 officials, and 5 musicians who sang political songs for each party adding up to 10 musicians. Purposive was used to identify the politicians who were employed musicians for P.F and UPND and 10 musicians who composed and performed political songs for the political parties. Random sampling was used to come up with voters who took part in the study. Open ended questionnaire, focus group discussion guide and an interview guide were used to collect data.

Four focus group discussions were held with voters in four provinces of Zambia. The maximum number of participants was eight per group. This gave an opportunity for the researchers an opportunity to hear experiences and feelings on the topic at hand from every participant. Interviews were held with the musicians. These allowed the researchers to get an in depth understanding on the topic under investigation. A questionnaire was used to collect data from politicians because they were not in office to allow an interview to take place. This enabled the researchers to get a detailed written response of views on the topic at hand. Data was analyzed according to themes that emerged in line with the research questions. Responses were grouped and a detailed interpretation was given in line with the main research question.

\section{RESUltS AND DISCUSSION}

\subsection{The Influence of Music on Voters}

\section{a. Responses from Voters?}

The respondents established that their voting was not mainly based on who they saw coming to campaign but the popularity of the candidate. One respondent mentioned, "I have never seen any of these presidents I hear, but I know them through the music they used for campaign and that is how I voted for one." Another respondent pointed out, "I only knew two political parties namely PF and UPND because their songs were popular. Even when I went to vote, I had to choose from the two." Another respondent mentioned, "The music for PF was live and danceable, through that, they were popular and people voted for them." Other views expressed revealed that voters voted a given political party because of the popularity of the music used as it acted as a crowd puller to wherever such music played.

\section{b. Responses from Musicians}

Another respondent noted, "Media was the only platform politicians used. So, we ensured that we designed special music which could play on all radio and TV stations to sell our candidates." Another 
musician mentioned that music in our province was used to unite the voters to vote for a common goal, liberation, and to have a perfect leader who is corruption free. Generally, musicians revealed that music was the best weapon they used to sell their pay masters because every person had a way of learning on the candidates who took part in the elections.

\section{c. Responses from Politicians}

Politicians revealed that they used music as a tool for campaign because it was the best instrument which pulled people to the larries in all the provinces they visited. One respondent explained, "We ensured that we had the best songs which infused our manifesto as a party for our presidential campaigns. We also sponsored the musicians to be with our campaign team so that before the presidential candidate could speak, the music itself told the whole story." Another respondent noted, "Music remained campaigning even when we left the podium. It was the best way of sending people home with the picture of the candidate they were to vote for. Through music, votes were realised unlike the parties which did not use good music." The respondents established that music was used to capture voters for their different candidates during elections. It provided the energy for voters to vote with an informed consent on the advantages and disadvantages of one leader against the other.

\section{d. Discussion}

The findings agree with Lumpa (2016) who explains that the political parties were using music power to try and help influence the 2016 Presidential election. The song "DonchiKubeba" helped Sata on the trail by reminding voters of his victory and wise counsel in the 2011 battle against the Movement for Multi-Party Democracy. Music has united the nation. It has held Zambia together. It has helped ferment political revolutions as well. Music has also helped to teach our nation that leadership is rotational and not for one person or party only. The study revealed that voters voted for a given political party because of the popularity of the music it used as it acted as a crowd puller to wherever such music was played. This finding is similar to Franz and Ridout (2007) who found that advertising influenced vote choice in several U.S. Senate races in 2004 and in that year's presidential election. They, too, found that advertising had a significant impact on vote choice. Music was a form of advertising which the politicians adopted in order to sell their party manifesto to the voters. Brader (2005) also added that the songs by Zambian musicians such as PK Chishala's 'Common man' were also used by then opposition MMD as a way of expressing the social, economic and political reality and dissatisfaction towards the United Nations Independence Party (UNIP) during campaigns. The campaign songs were well composed in the manner that they infiltrated the message the politicians wanted to express to the Zambians. Developmental issues were highlighted on what each leader will do for the people and why the voters should give such a candidate a vote was explained. Indeed, the battle between politicians is for a vote from a common man whose rights and freedom is uncertain. As much as the town voters were able to point at the running and complete developmental projects of economical significance, the rural community was able to point from a distance the abandoned projects like clinics, unrepaired bridges and the late delivered farming inputs.

\subsection{Reasons Politicians Use Musicians in Political Campaigns}

\section{a. Responses from Voters}

Respondents established that music was used by politicians extensively so that every voter and would be voter could get the campaign messages from any corner of the country at any time. One respondent mentioned that, "music was used in order to pass their special message to the voters which could not be passed to them at a single larry." Another respondent explained, "politicians played loud music to make their names be known since most of them just come during campaign." After the voting was done, very few songs play of political campaigns.

\section{b. Responses from Musicians}

The musicians thought that politicians came to them for collaboration because they had the audience and the voice to speak to the people while politicians had the message. One respondent noted, "Our role as musicians is to inform, educate and entertain. It was this that the politicians followed. We helped them inform the masses about their plans; we educated the people whilst they got entertained." Another respondent explained, "Every politician who knows politics came to us because our industry 
had celebrities who, when they stand, every person would like to shake hands, talk to them and listen to their music live on stage. Our inclusion in the campaigns made us more exposed, popular while the politicians were gaining popularity and political mileage."Another respondent said, "Music is a uniting factor in the Zambian society. Despite the political differences, music brought all the people together and danced in bars, night clubs and functions to enjoy the rhythm. It united the voters and asked them to vote for what they were seeing so that changes in their lives could be seen too." Other musicians narrated that they also sang songs which encouraged peace during and after elections which were not fully paid for but provided a platform for every Zambian to realise what would happen if they mismanaged the peace they enjoyed.

\section{c. Responses from Politicians}

Music was used by politicians for various reasons during the campaigns. One respondent mentioned, "We used music to sell our party manifesto because music goes beyond the boarders of our campaign zone. Music is like bush fire, it is played everywhere. Even during functions, people where busy doing 'dununa reverse and forward." Another respondent said, "the Zambian society is made up of music, it was then important that we use what people like to convey our message. This is why we used music." Another respondent revealed, "we used musicians to show that Zambia was not one tribe but many. The different musicians on stage used represented different tribes hence music acted as a uniting factor which helped push the One Zambia One nation agenda." Through music, the politicians reached their audience countrywide with fewer difficulties.

\section{d. Discussion}

The study revealed that musicians are well known to the population because they are the talk of the day on every media platform through the music they play. Politicians are also well known people in the country for being leaders. The combination of the two celebrities on one stage attracted people to watch and listen to the political messages. The findings are concretized by Franz et al (2010) who said that various genres and styles of popular music are employed in strategies of political propaganda not only to promulgate a political message and make it sound persuasive but also to bring people from various strata of society together in support of an ideological and/or propagandistic objective. The politicians and musicians in this case had followed the required standard to sell themselves to the countrymen and women.

Further findings of the study revealed that musicians and politicians shared the same stage to show Zambians that despite them belonging to different tribes, they are able to work together and push the one Zambia one nation agenda through music. This finding corresponds with Serge, (1969) views that hold that music is used to influence people's actions and "achieve organizational cohesion" for both ideological and propagandistic purposes at all levels. Additionally, Frith (1987) claimed, "Pop songs and pop stars" mean more to us emotionally than other media events or performers. The experience of pop music is an experience of placing: in responding to a song, we are drawn, haphazardly, into affective and emotional alliances with the performers and with the performers' other fans" and for our purposes here, the politician using the music. From the Zambian political scene, the findings are supported by Wilson (2016) who holds that Petersen Zagaze and, now Pilato have also gone into the political fray. Pilato with his controversial 'AlunguAnabwela' which saw him in some form of interrogations for deformation of character won a lot of supports which supported the opposition parties

\subsection{Reasons for Choosing a Language in a Political Music}

The respondents said that the popularity of Bemba, Nyanja and English in the country was the motivating factor for using the three languages. Media houses uses Bemba, Nyanja and English to communicate to the entire population and they were widely spoken in Zambia. One respondent cited the popularity of Bemba and Nyanja in the country being the motivating factor for using the two languages. One respondent stated, "When we are campaigning on television and radio to the whole country, we use Bemba, Nyanja and English so that every Zambian could hear our message. Even when composing a son, these are the target language we used because they are popular." Another respondent said; "we used Nyanja, Bemba and some English because these are the national languages to be frank. They are spoken and heard by majority Zambians who were our target."Another 
respondent explained that music was meant for the most populated areas where votes could come from yet people do not attend political gatherings due to their busy schedules. She further lamented that, "the largest population of voters is found along the line of rail and provincial centres where Bemba or Nyanja is widely used. So to capture these votes, the two languages were used in our music." Local musicians also used the local languages in their districts to sell their pay masters in their areas

\section{a. Discussion}

In line with the forgoing findings, Chanda (2014) attests that communication is perfectly done to the public when the speaker uses the common language which the audience is familiar with. In this case, the two languages proved to be the widely used languages in Zambia because when one of the two languages is used to a stranger, communication will take place most likely. The choices regarding the language used in communicating to a given audience is the matter of who the target is. In this case, the majority Zambians speaks and understands the Nyanja, Bemba and English as an official language.

The combination of the languages was as a result of the fact that many people understood messages spoken in Nyanja, Bemba and English hence musicians and politicians chose the two languages. The finding is supported by the CSO (2010) which found that Zambia's most widely spoken languages are Bemba (spoken by $42 \%$ of the population as either a first or second language), Nyanja (37\%), Tonga $(09 \%)$ and Lozi $(06 \%)$ and the rest is for other languages. Of the international languages, over $95 \%$ of the Zambian who are elite speak and or understand English language and the two languages because they are found in the cities where universities and colleges are located.

\section{CONCLUSIONS AND RECOMMENDATIONS}

\subsection{Conclusions}

The study concluded that;

- Well composed political music has a huge influence on the candidate people will vote for in a given election. Voters listen to political music more than to the political rallies during the campaign period. Therefore, their voting is influenced by the messages they get from the music they listen to.

- Politicians use musicians in order to attract the citizens to attendance of their political lallies in various parts of the country. They use renowned musicians so as to pull as many potential voters as they can and sell their party manifesto.

- The popularity of the musicians used adds value to the politicians on stage. This helps the politicians to talk little since many words are in the song performed before the stage and or on radio.

- Politicians and musicians use Bemba, Nyanja and English in their political music so as to enable all the Zambians in the country to make meaning of the music. The three languages are used by the largest population in the country.

\subsection{Recommendations}

In the view of the above mentioned, the following recommendations are made

- Political music should not be composed as a conveyer of propaganda, but should continue informing the nation on the development and failures being undergone in the nation throughout the term of rule. This will help the country reduce finger pointing as to who was in support of one party and not for the other one and bring unity of purpose.

- Voters should compare what they hear from the music with the reality on the ground so that they are able to cast a vote from an informed and practical decision. This will help the voters to refute some songs which are flowery and lack practical evidence.

- As much as musicians work for money from the politicians, they have to stand their ground of informing, entertaining and educating. They have to refuse to be used as tools for spreading 
propaganda and ridicule of one person for the sake of another person. This will help politicians to unite because musicians will no longer have camps within the industry.

- More regional languages have to be used in order to promote the one Zambia one nation slogan despite Bemba, Nyanja and English being the widely used languages. The few voters who do not understand the three languages will also be given a platform to listen to what the politicians are saying to the voters. This may also reduce the notional of thinking that one language is superior to the other.

\section{ACKNOWLEDGEMENTS}

We would love to record our gratitude to the voters in the sampled provinces, the musicians and the politicians for participating in this study as primary data sources. Without your participation, this study would have not been possible.

\section{REFERENCES}

[1] Bochkarev, H. (2012). Analysing Popular Music. Popular Music, 2, 37-67.

[2] Brader, T. (2005). The Role of Advertising in Persuading Voters in Politics. Journal of Political Science. 49(6): $288-405$

[3] CSO (2010). National Statistics Bulletin for the 2010 Census. CSO: Lusaka.

[4] Chanda, Y. (2014). The Invention of "Folk Music" and "Art Music" Emerging Categories from Ossian to Wagner. New York: Cambridge University Press.

[5] Chimuka, S. S. (1977). Zambian languages: orthography approved by the Ministry of Education. Lusaka : National Educational Company of Zambia (NECZAM).

[6] Cogan, B. and Kelso, T. (2009). Encyclopedia of Politics, the Media, and Popular Culture. Santa Barbara, CA: Greenwood

[7] Dunaway, D. K. (1987). Music and Politics in the United States.Folk Music Journal. Vol. 5, No. 3 pp. 268-294.

[8] Gavish, E. (2009). Music has always been a tuneful force for political change. Francisco: Daily Entertainment Inc.

[9] Goldstein, K. \& Freedman, P. (2002). Campaign Advertising and Voter Turnout: New Evidence for a Stimulation Effect. The Journal of Politics, 64(3), 721-740

[10] Hayden, L. (1962). Towards an aesthetic of popular music. In R. Leppert\& S. McClary (Eds.), Music and society: The politics of composition, performance and reception (pp. 133-150). Cambridge, UK: Cambridge University Press

[11] Huber, G.A. and Arceneaux, K. (2007). Identifying the Persuasive Effects of Presidential Advertising. American Journal of Political Science, 51(4), 957-977

[12] Lumpa, M.(2016).The Power of Music in Zambian History. The University of Zambia Collection. UNZA Press.

[13] Munshya, W. (2014). Music and the Politics of Leaders. A Cultural Diversity Platform. Challenge Magazine 5 (12) 11-12.

[14] Philip, A. (2012). Musical Persona: The Physical Performance of Popular Music," in The Ashgate Research Companion to Popular Musicology, 314

[15] Philip, C. (2012). The Maluf in Contemporary Libya: An Arab Andualusian Musical Tradition. Ashgate. 5(1) $12-16$

[16] UNESCO. (1953). Music in Education International Conference on the Role and Place of Music in the Education of Youth and Adults Brussels, 29 June to 9 July 1953

[17] Washington Post, "Donald Trump blames Mitt Romey’s 2012 loss on Paul Ryan," Feb. 17, 2016

[18] Woods, J. (2012). Recording Industry Association of America, Rockthevote.com, Juice Magazine, Rolling Stone.

\section{AUTHOR'S BIOGRAPHY}

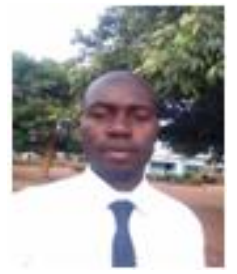

Nyimbili Friday is a teacher of English language and literature at Chikomeni day secondary school in Lundazi district and a part time lecturer at University of Africa. $\mathrm{He}$ is also a PhD student at the University of Zambia in Applied Linguistics. He also provides research consultation and he is a part time editor at Lusaland Investment. 


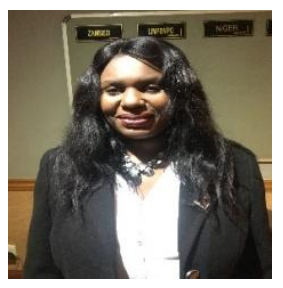

Namuyamba Mubita is a Part Time Lecturer and researcher in the Department of Adult Education and Extension Studies at the University of Zambia. She is also a Clinical Officer at UNZA Health Services. She also provides capacity building consultancy in various organizations.

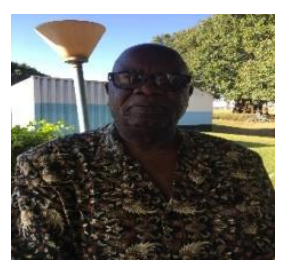

Chakanika W. Wanga is DIRECTOR of Chalimbana University College. Senior Lecturer- University of Zambia, School of Education, Lusaka.

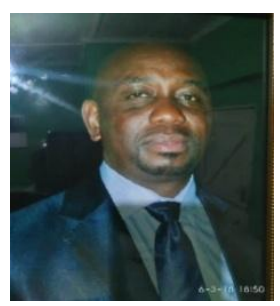

Munkombwe Conrad is a Researcher and writer. Head of Section for Intergrated Sceince at Njanse Secondary School Senior Teacher, Ministry of Education, Zambia. He holds MAE and BAED from the University of Zambia.

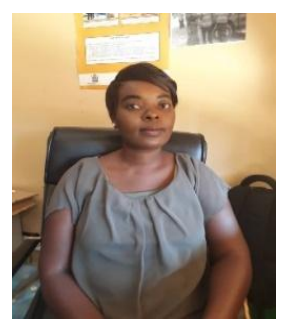

Kabwe Chisenga Senior Community Development Officer - Ministry of Community Development and Social Services, Zambia. Former Postgraduate Student (Master of Education in Adult Education), University of Zambia

Phiri Davies is a Lecturer, and researcher at the University of Zambia Department of Adult Education and Extension Studies

Citation: Mubita Namuyamba et al "Music and its Role in the Electoral Process of Zambia". International Journal of Humanities Social Sciences and Education (IJHSSE), vol 5, no. 6, 2018, pp. 39-47. doi: http://dx.doi.org/10.20431/2349-0381.0506006.

Copyright: (C) 2018 Authors. This is an open-access article distributed under the terms of the Creative Commons Attribution License, which permits unrestricted use, distribution, and reproduction in any medium, provided the original author and source are credited. 